\title{
In Situ Mantle Cell Neoplasia
}

National Cancer Institute

\section{Source}

National Cancer Institute. In Situ Mantle Cell Neoplasia. NCI Thesaurus. Code C138191.

A neoplastic lymphoid process characterized by the presence of cyclin D1 positive lymphoid cells, typically in the inner mantle zones of lymphoid tissue follicles, in cases that do not suggest the diagnosis of a mantle cell lymphoma. It is often found incidentally and has a low rate of progression. 